\title{
Aluminum induces rapidly mitochondria- dependent programmed cell death in Al-sensitive peanut root tips
}

\author{
Wen-Jing Huang ${ }^{\dagger}$, Thet Lwin Oo ${ }^{\dagger}, \mathrm{Hu}-\mathrm{Yi}$ He, Ai-Qin Wang, Jie Zhan, Chuang-Zhen Li, Shan-Qing Wei \\ and Long-Fei He*
}

\begin{abstract}
Background: Although many studies suggested that aluminum (Al) induced programmed cell death (PCD) in plants, the mechanism of Al-induced PCD and its effects in Al tolerance is limited. This study was to investigate the mechanism and type of Al induced PCD and the relationship between PCD and Al tolerance.

Results: In this study, two genotypes of peanut 99-1507 (Al tolerant) and ZH2 (Al sensitive) were used to investigate Al-induced PCD. Peanut root growth inhibition induced by $\mathrm{AlCl}_{3}$ was concentration and time-dependent in two peanut varieties. $\mathrm{AlCl}_{3}$ at $100 \mu \mathrm{M}$ could induce rapidly peanut root tip PCD involved in DNA cleavage, typical apoptotic chromatin condensation staining with DAPI, apoptosis related gene Hrs203j expression and cytochrome C (Cyt c) release from mitochondria to cytosol. Caspase3-like protease was activated by Al; it was higher in $\mathrm{ZH} 2$ than in 99-1507. Al increased the opening of mitochondrial permeability transition pore (MPTP), decreased inner membrane potential $\left(\Delta \psi_{\mathrm{m}}\right)$ of mitochondria. Compared with the control, Al stress increased $\mathrm{O}_{2}{ }^{-}$and $\mathrm{H}_{2} \mathrm{O}_{2}$ production in mitochondria. Reactive oxygen species (ROS) burst was produced at Al treatment for $4 \mathrm{~h}$.

Conclusions: Al-induced PCD is earlier and faster in Al-sensitive peanut cultivar than in Al-tolerant cultivar. There is a negative relationship between PCD and Al resistance. Mitochondria- dependence PCD was induced by Al and ROS was involved in this process. The mechanism can be explained by the model of acceleration of senescence under Al stress.
\end{abstract}

Keywords: Al toxicity; Programmed cell death; Arachis hypoganea L; Caspase3-like; Mitochondria; Reactive oxygen species burst

\section{Background}

Aluminum ( $\mathrm{Al})$ is the most abundant metal in the earth's crust. $\mathrm{Al}$ presents in various forms including $\mathrm{Al}^{3+}, \mathrm{Al}(\mathrm{OH})^{+}$ and $\mathrm{Al}(\mathrm{OH})^{2+}$ in soil solution as soil $\mathrm{pH}$ drops below 5 , and these are harmful to crops. Therefore, Al toxicity is considered as a major limiting factor for crop production and quality in acid soil, which comprises $30-40 \%$ of the world's arable lands (Pan et al. 2001). Al affects root growth through acting in the root apical zone, resulting in growth inhibition in a very short time at micro molar concentrations (Panda and Matsumoto 2007). Plant

\footnotetext{
* Correspondence: Ifhe@gxu.edu.cn

${ }^{\dagger}$ Equal contributors

College of Agronomy, Guangxi University, Daxue Road 100, Nanning 530004, PR China
}

species have evolved diverse mechanisms of Al tolerance, including the secretion of $\mathrm{Al}$-induced organic acids, immobilization of $\mathrm{Al}$ at cell wall, and increasing in rhizosphere $\mathrm{pH}$ (He et al. 2012).

Programmed cell death (PCD) known as apoptosis, has been described in animal cells in detailed at morphological, biochemical, and genetic levels. Similar to animal cells, plant cells can also respond to various stimuli, including biotic and abiotic stresses as well as development by initiating PCD (Wang et al. 2011). PCD is associated with specific morphological and biochemical features such as nuclear DNA degradation (Achary and Panda 2010; Fu et al. 2003; Qiao et al. 2003), specific proteases activation (Poor et al. 2013), plasma membrane embolus or chromatin condensation (Wang et al. 2012),

\section{黑 Springer}


Cyt $c$ release from mitochondria to cytoplasm (Wang et al. 2010), mitochondrial permeability transition pore (MPTP) opening and mitochondrial membrane potential collapse (Panda et al. 2008; Toninello et al. 2000). Increasing evidences show that Al-induced PCD plays a significant role in Al tolerance of plants, animals and yeasts (Wang et al. 2009; Yakimova et al. 2007; Zheng et al. 2007). Researches have described some apoptosis-like characters upon Al treatment in plant cells, including the appearance of DNA ladder, changes in nucleus morphology, and the fragmentation of nucleus (Panda and Matsumoto 2007). They also determined the potential roles of anti-apoptotic members in Al tolerance (Yakimova et al. 2007).

Mitochondria play a vital role in eukaryote life. The mitochondrial pathway of apoptosis functions in response to various types of stress including $\mathrm{Al}$ in both animal (Toninello et al. 2000) and plant cells (Panda et al. 2008; Poborilova et al. 2013; Yamamoto et al. 2002). In most cases of mitochondria-dependent PCD, Cyt $c$ is released from mitochondria dues to the opening of a MTPT and the activation of caspase protease (Kim et al. 2006). On the other hand, mitochondria is unique organelle which carries out important oxidation-reduction reactions. It has been considered as major reactive oxygen species (ROS) producers in animal cells and plant cells without chloroplasts, such as root cells (Tiwari et al. 2002). Excess generation of ROS is metabolically induced by abiotic and biotic stresses in plant cells (Foyer and Noctor 2000). ROS are not only a harmful factor to plants because they react with a large variety of biomolecules, including DNA, proteins, and carbohydrates (Siddiqui et al. 2013), but also a signaling molecule in plants which mediates various physiological and biochemical processes (Mittler et al. 2004) including systemic acquired resistance (SAR) and hypersensitive resistance (HR) (Huang et al. 2004), senescence and PCD (Liu and Lin 2013; Matsumoto and Motoda 2013; Wei et al. 2013; Xing et al. 2013).

As an importance oil and food crop, peanut (Arachis hypoganea L.) is usually planted in acid soil in the south of China, and has high Al tolerance capacity compared to other crops. The mechanism of Al toxicity and tolerance of peanut is not uncovered. Zhan et al. (2011) reported firstly $\mathrm{Al}$ induced $\mathrm{PCD}$ in peanut, and the cloned AhSAG (a senescence-associated gene) could induce or promote the occurrence of PCD in plants. Unfortunately, it should take 4 days for $\mathrm{Al}$ inducing $\mathrm{PCD}$ in the report (Zhan et al. 2013). The type of Al-induce PCD could not be determined in peanut, and the mechanism and regulation referred to PCD have poorly understood. The aim of our present work is to certify the phenomenon and type of Al-induced PCD in peanut in a short time, and assess the behavior of mitochondria as well as the activation of caspase-3-like activity under Al treatment. Based on the results obtained from cell imaging and biochemical approaches, it can provide a new insight into the mitochondria-dependent mechanism of Al-induced PCD in peanut root tip cells.

\section{Methods}

\section{Plant materials and treatment}

Plant materials and treatment were prepared as described by Zhan et al. (2008) with slight modifications. The seeds of peanut cultivars 99-1507 (Al-tolerant) and $\mathrm{ZH} 2$ (Al-sensitive) were germinated in moistened sand for 5 days in the dark at $26^{\circ} \mathrm{C}$. Three cm-length root seeds were transferred in the $1 / 5$ Hoagland nutrient solution which was exchanged at an intervals of 1 day. After the emergence of the fourth leaf, the seedlings were pretreated with $0.1 \mathrm{mM} \mathrm{CaCl}_{2}(\mathrm{pH} 4.5)$ solution for $24 \mathrm{~h}$. Some seedlings were treated respectively with different $\mathrm{AlCl}_{3}$ concentrations $(0,20,50,100,200$ and $400 \mu \mathrm{M})$ ( $\mathrm{pH} 4.5$ ) followed by $0.1 \mathrm{mM} \mathrm{CaCl}_{2}$ for $24 \mathrm{~h}$, and $\mathrm{pH}$ was adjusted by $\mathrm{HCl}$. The others were treated respectively with $100 \mu \mathrm{M} \mathrm{AlCl} \mathrm{Al}_{3}$ concentrations $(\mathrm{pH} 4.5)$ at different times $(0,4,8$ and $12 \mathrm{~h})$ followed by $0.1 \mathrm{mM} \mathrm{CaCl}_{2}$. The plants were grown in a self-regulating culture room with a $12 \mathrm{~h} /$ $26^{\circ} \mathrm{C}$ day and a $12 \mathrm{~h} / 20^{\circ} \mathrm{C}$ night cycle.

\section{Assay of relative root elongation}

Effects of $\mathrm{Al}$ on different peanut cultivars root growth were observed by measuring the main root length. The relative root elongation (RRE) was calculated through the formula: $\mathrm{RRE}=\mathrm{L}_{24 \mathrm{~h}}-\mathrm{L}_{0 \mathrm{~h}} / \mathrm{L}_{24 \mathrm{~h}}$.

\section{Light microscopy (LM) observation}

Tissue sections were prepared by Gladish et al. (2006) with some modifications. Tip segments at 5-10 mm long ( $\mathrm{n}=5-10$ for each treatment) were excised and treated in osmotically balanced FAA fixative solution buffer $(\mathrm{pH} \mathrm{7.2)}$ at least $12 \mathrm{~h}$. Then, the segments were rinsed in $\mathrm{ddH}_{2} \mathrm{O}$ three times and dehydrated through a graded series of ethanol $(40,50,65,80,90,100,100 \%$, $20 \mathrm{~min}$ for each step).

Dehydrated root tip segments were embedded in Steedman's Wax (Polyethylene glycol 400 distearate : 1hexadecanol $=9: 1, \mathrm{w} / \mathrm{w})$ as described by $\mathrm{He}$ et al. (2004) via a graded series Steedman's Wax : ethanol-1 : 1, $2: 1,1: 0,2 \mathrm{~h}$ each step. Embedded root segments were sectioned at $10 \mu \mathrm{m}$ with a Leica RM2255 ultramicrotome (Leica Instruments $\mathrm{GmbH}$, Heidelberg, Germany) and mounted on glass slides. Nine or ten embedded root segments were selected at random and sectioned for each treatment. Some sections were stained in solution buffer

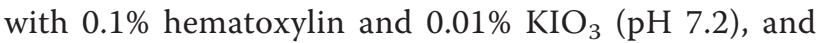
observed via bright-field LM for $\mathrm{Al}$ absorption analysis. Other sections were stained with $1 \mathrm{mg} \mathrm{L}^{-1}$ DAPI 
(4, 6-diamidino-2-phenylindol dihydrochloride) in $\mathrm{ddH}_{2} \mathrm{O}$ for $5 \mathrm{~min}$, observed and visualized on $340-380 \mathrm{~nm}$ excitation with a Leica DM4000B fluorescence microscope in order to analyze nuclear changes and count PCD rate after Al treatment. The PCD rate was calculated with the percentage of apoptosis cells to total cells. Apoptosis cells morphological changes include chromatic agglutination, karyopyknosis, and nuclear fragmentation in some cells under microscope. More than 50 random fields $(400 \times)$ were observed and calculated respectively by three individuals.

\section{Determination of Al Content}

One-week-old seedlings were treated with $100 \mu \mathrm{M} \mathrm{AlCl} \mathrm{Al}_{3}$ ( $\mathrm{pH} 4.5)$ for different times $(0,4,8$ and $12 \mathrm{~h}$ ), followed by $0.1 \mathrm{mM} \mathrm{CaCl}_{2}$, which were used for determination of Al content (Barry and Adam 1984; He and Liang 1996). At first, the sample was washed twice with distilled water, cut apical $( \pm 10 \mathrm{~mm}$ section) from the root tip, weighed, and soaked in $1.5 \mathrm{~mL}$ of $2 \mathrm{mM} \mathrm{HNO}_{3}$ solution for $24 \mathrm{~h}$. The soaking solution was transferred into 25 $\mathrm{mL}$ volumetric flask, and $1 \mathrm{~mL} 0.1 \mathrm{mM} \mathrm{HNO}_{3}, 2 \mathrm{~mL} 5$ mM CTMAB (cetyltrimethyl ammonium), $2 \mathrm{~mL} 50 \mathrm{mM}$ EDTA-Zn were added, then was shaked thoroughly for 2 min. $2 \mathrm{~mL} 0.05 \%$ chromazurol-S chromogenic reagent, 4 $\mathrm{mL} \mathrm{40 \%} \mathrm{hexamethylenetetramine} \mathrm{solution} \mathrm{was} \mathrm{added} \mathrm{in}$ proper order. Finally, the flask was filled using distilled water, shaked well and took $30^{\circ} \mathrm{C}$ for $20 \mathrm{~min}$. Meanwhile, $\mathrm{Al}$ standard solution was prepared for the standard curve. Absorbance was measured at $635 \mathrm{~nm}$ and calculated the content of $\mathrm{Al}$ by spectrophotometer (VIS-723).

\section{DNA fragmentation}

After Al treatments, peanut roots of 99-1507 and ZH2 were firstly washed in running tap water, and then washed twice with $\mathrm{ddH}_{2} \mathrm{O}$ thoroughly. Each root was cut in $10 \mathrm{~mm}$ section from the root tip, weighed $0.3 \mathrm{~g}$, and was homogenized in liquid nitrogen. DNAs were extracted by the CTAB protocol (Wang et al. 2009). DNA samples were digested with $10 \mu \mathrm{L} 100 \mu \mathrm{gmL}^{-1} \mathrm{DNase}-$ free RNase and $20 \mu \mathrm{L} 10 \mathrm{mg} \mathrm{L}^{-1}$ Proteinase $\mathrm{K}$ for $1 \mathrm{~h}$ at $37^{\circ} \mathrm{C}$, then resuspended in $50 \mu \mathrm{L}$ of TE buffer. Fifty $\mu \mathrm{L}$ DNA samples were loaded into $6 \times$ loading buffer with nucleic acid dye GelRed. DNA fragments were checked on agarose gel (2\%) electrophoresis at $50 \mathrm{~V}$ for $30 \mathrm{~min}$. Results were photographed under UV excitation.

\section{Expression analysis of $\mathrm{Hsr} 203 \mathrm{j}$}

The expression of $H s r 203 j$ in root tip cells was analyzed by semi-quantitative RT-PCR (Ma et al. 2010). Samples were harvested separately at $0,4,8$ and $12 \mathrm{~h}$ after $100 \mu \mathrm{M}$ $\mathrm{AlCl}_{3}$ treatment. Total RNA was extracted with Trizol reagent protocol (Catalog No. 15596-018; Invitrogen). cDNA was synthesized from total RNA with M-MLV
Reverse Transcriptase kit (Catalog No. 1621; Fermentas). The specific primers for $\mathrm{Hsr} 203 j$ were 5-TTTGAGAC TTGCCTTACCTG-3' and 5'-TTACTTACCCGGAGAT TACA-3', were designed according to the published cDNA (GenBank accession No.GU827198). The primers of positive control actin were 5'ACCTTCTACAACGAGCTT CGTGTG-3' and 5'-GAAAGAACAGCCTGAATGGCAA C-3' (Zhan et al. 2011). Each PCR reaction was carried out in final volume of $25 \mu \mathrm{L}$, containing $10 \mathrm{ng}$ of first-strand cDNA, $2.5 \mathrm{mM} \mathrm{MgCl}_{2}, 10 \mu \mathrm{M}$ PCR primers, $2 \mathrm{mM}$ dNTP and $0.5 \mathrm{U}$ Taq DNA polymerase in $10 \times$ PCR buffer. All reactions were run for 28 cycles, each consisting of $30 \mathrm{~s}$ at $94^{\circ} \mathrm{C}, 30 \mathrm{~s}$ at $56^{\circ} \mathrm{C}, 45 \mathrm{~s}$ at $72^{\circ} \mathrm{C}$, with an initial activation step of $5 \mathrm{~min}$ at $94^{\circ} \mathrm{C}$ and an extension step of $10 \mathrm{~min}$ at $72^{\circ} \mathrm{C}$. The PCR products were checked on agarose gels (1\%) by electrophoresis.

\section{Measurements of caspase3-like protease activity}

Cytosolic fractions from Al-treated root tip cells were used to assay caspase3-like protease (Wang et al. 2010), according to the manufacturer's instruction (Caspase-3 Activity Assay Kit, 'Beyotime, China). Protein concentration was determined by Bradford's method (1976). Equal amounts of total protein extracts $(15 \mu \mathrm{g})$ were incubated for $12 \mathrm{~h}$ at $37^{\circ} \mathrm{C}$ with synthetic tetrapeptide DEVDp-nitroaniline(pNA), and the addition of the substrate resulted in a signal caused by the caspase3-dependent cleavage of the chromophorepNA from the labeled substrate. Caspase3-like activity was measured at $405 \mathrm{~nm}$ by microplate reader iMaker (BIO-RAD, USA). Enzymatic activity was expressed as absorbance at $405 \mathrm{~nm}$. Each measurement was carried out with three independent experiments.

\section{Separation of mitochondria from peanut root tip cells}

Mitochondria were isolated by the method of Panda et al. (2008) with some modifications. Peanut roots treated by $100 \mu \mathrm{M} \mathrm{AlCl}$ for $0,4,8$ and $12 \mathrm{~h}$ were washed separately in distilled water. Then, the roots were cut about $3 \mathrm{~g}$, put into the mortar, and grinded in the presence of mitochondrial extract $5 \mathrm{~mL}(0.4 \mathrm{M}$ sucrose, $50 \mathrm{mM}$ pH 7.4 Tris-HCl buffer, $1 \mathrm{mM}$ EDTA) on ice-bath. The homogenates were centrifuged at $1500 \times \mathrm{g}$ for $15 \mathrm{~min}$ and supernatants were centrifuged at 14 $000 \times \mathrm{g}$ for $15 \mathrm{~min}$. The mitochondrial precipitates were washed 3 times with the mitochondrial suspension buffer (except EDTA, the other with the preparation liquid). The final pellets containing mitochondria were made for an appropriate volume with suspension buffer and used immediately for all experimental purposes without storage. Suspensions stained with $0.02 \%$ Janus Green B were tested by oil lens of microscope to verify the quality of mitochondria. Protein concentration was determined by Bradford's method (1976). 


\section{SDS-PAGE and detection of Cyt $c$ release}

Twenty $\mu \mathrm{g}$ mitochondrial proteins were separated in a $12 \%(w / v)$ SDS-PAGE. After electrophoresis, the separated proteins were transferred into nitrocellulose membrane (Catalog No. FFN06, Beyotime, China), and were wetted with blocking buffer (Catalog No.P0023B, Beyotime, China) at least $1 \mathrm{~h}$. After three times washing by washing buffer (Catalog No. P0023C, Beyotime, China) for 5-min each time, cytochrome $c$ was probed with a primary antibody against mouse cytochrome $c$ (1: 200 dilution, Catalog No. AC909, Beyotime, China) overnight. After three vigorous washings in the same washing buffer for $15 \mathrm{~min}$, each membrane was incubated with a goat anti-mouse conjugated with horseradish peroxidase conjugate (1: 1000 dilution, Catalog No. A0216, Beyotime, China) at room temperature for $2 \mathrm{~h}$. After several washes with washing buffer, the membrane was transferred to DAB assay reagents (Catalog No. P0203, Beyotime, China) for chromogenic detection.

\section{Measurement of mitochondrial membrane permeability} Isolated mitochondria were suspended with $0.2 \%(\mathrm{w} / \mathrm{v})$ BSA, and the concentration of mitochondrial proteins was adjusted approximately $0.3 \mathrm{mg} \mathrm{mL}^{-1}$. For mitochondrial membrane permeability detection, the absorbance at $540 \mathrm{~nm}$ was determined with a spectrophotometer (Zhan et al. 2009; Zhang and Xing 2008).

\section{Measurement of mitochondrial inner membrane potential $\left(\Delta \Psi_{\mathrm{m}}\right)$}

Mitochondria $\left(0.1 \mathrm{mg}\right.$ protein $\left.\mathrm{mL}^{-1}\right)$ were incubated in a buffer $(220 \mathrm{mM}$ sucrose, $68 \mathrm{mM}$ mannitol, $10 \mathrm{mM} \mathrm{KCl}$, $5 \mathrm{mM} \mathrm{KH}_{2} \mathrm{PO}_{4}, 2 \mathrm{mM} \mathrm{MgCl} 2,500 \mu \mathrm{M}$ EGTA, $5 \mathrm{mM}$ succinate, $2 \mu \mathrm{M}$ rotenone and $10 \mathrm{mM}$ HEPES, pH 7.2) supplemented with $10 \mu \mathrm{g} \mathrm{mL}{ }^{-1}$ rhodamine 123(Rh-123) for 5 min. $\Delta \Psi_{\mathrm{m}}$-dependent quenching of Rh-123 fluorescence (excitation $490 \mathrm{~nm}$, emission $535 \mathrm{~nm}$ ) was measured continuously in a spectrofluorometer (Braidot et al. 1998; Panda et al. 2008).

\section{Detection of mitochondrial ROS $\left(\mathrm{O}_{2}^{--}\right.$and $\left.\mathrm{H}_{2} \mathrm{O}_{2}\right)$}

The mitochondrial superoxide anion radical was quantified by the methods of Purvis (1997) and Panda et al. (2008) with purified mitochondrial suspension. NADHdependent superoxide generation was assayed at $25^{\circ} \mathrm{C}$ by superoxide dismutase (SOD)-sensitive rate of oxidation of epinephrine to adrenochrome with an increase in absorbance at $480 \mathrm{~nm}$ with $4.0 \mathrm{mM}^{-1} \mathrm{~cm}^{-1}$ as extinction coefficient.

$\mathrm{H}_{2} \mathrm{O}_{2}$ production in isolated mitochondria was measured by a non-enzymatic assay according to Panda et al. (2008). $20 \mu \mathrm{l}$ mitochondrial suspension was added into $880 \mu \mathrm{l}$ double-distilled water, followed by $100 \mu \mathrm{l} \mathrm{ti-}$ tanium sulfate. The reaction mixture was incubated for
$15 \mathrm{~min}$ at room temperature, and the oxidation of titanium sulfate was detected at $410 \mathrm{~nm}$ (UV160, Shimadzu, Japan). Absorbance was converted into $\mathrm{H}_{2} \mathrm{O}_{2}$ concentrations by using a $\mathrm{H}_{2} \mathrm{O}_{2}$ standard curve.

\section{Statistical analysis}

The experiments were independently replicated three times and their mean values were subjected to data processing and statistical analysis with Excel2007 and SPSS12.0. Data are represented as mean \pm SD. Statistical analysis was performed with the Student's paired $t$ test. Differences were considered statistically significant at ${ }^{*} P<0.05$, ${ }^{* *} P<0.01$.

\section{Results}

\section{Al accumulation in the root tips}

After $\mathrm{AlCl}_{3}$ (pH 4.5) stress for $24 \mathrm{~h}$, low Al concentration $(20 \mu \mathrm{M})$ could inhibit root growth significantly. Root growth of 99-1507 and ZH2 were almost arrested under $400 \mu \mathrm{M}$ Al treatment. There were highly significant different relative root elongation rate between $\mathrm{Al}$ tolerant $99-1507$ and $\mathrm{Al}$-sensitive $\mathrm{ZH} 2$ treated by $\mathrm{Al}$ at 50, 100 and $200 \mu \mathrm{M}$ (Figure 1). Thus, a moderate and effective $\mathrm{Al}$ concentration $(100 \mu \mathrm{M})$ was chosen to further study.

Al contents of 99-1507 and ZH2 in peanut root tips were analyzed by spectrophotometry. Al contents increased along with exposure time extending in two peanut varieties (Figure 2), and it was higher in $\mathrm{ZH} 2$ than in 99-1507. Al accumulation in root tips was observed using hematoxylin staining after $\mathrm{Al}$ treatment. $\mathrm{Al}$ accumulated mainly in the epidermis and cortex of root tips. The colors of hematoxylin staining in root tip cells treated by $\mathrm{Al}$ for $4 \mathrm{~h}$ were darker compared with the control (Al treatment for $0 \mathrm{~h}$ ). With the extension of $\mathrm{Al}$ treatment time, the color became deeply. Al accumulation was higher in $\mathrm{ZH} 2$ than in 99-1507 at the same $\mathrm{Al}$ stress time (Figure 3).

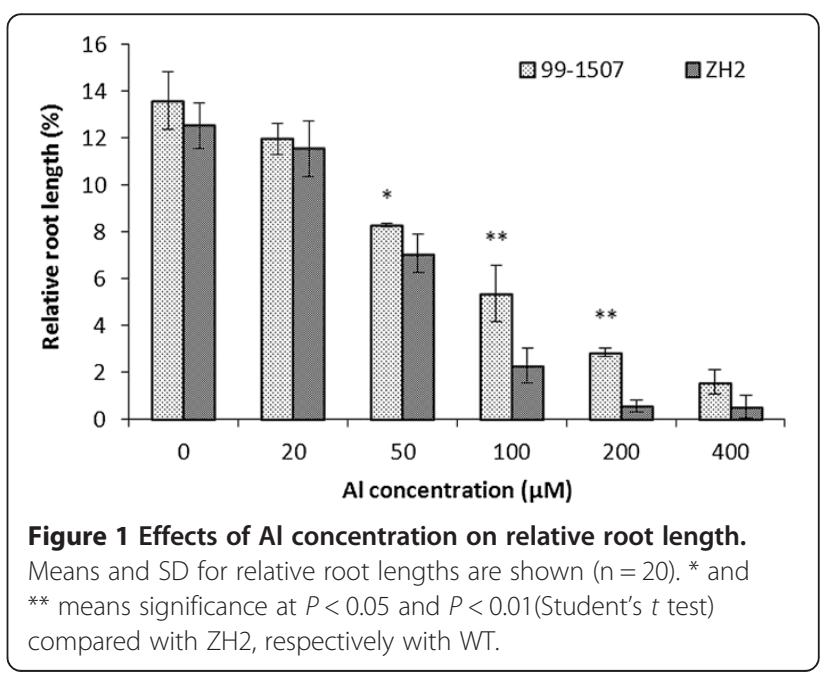




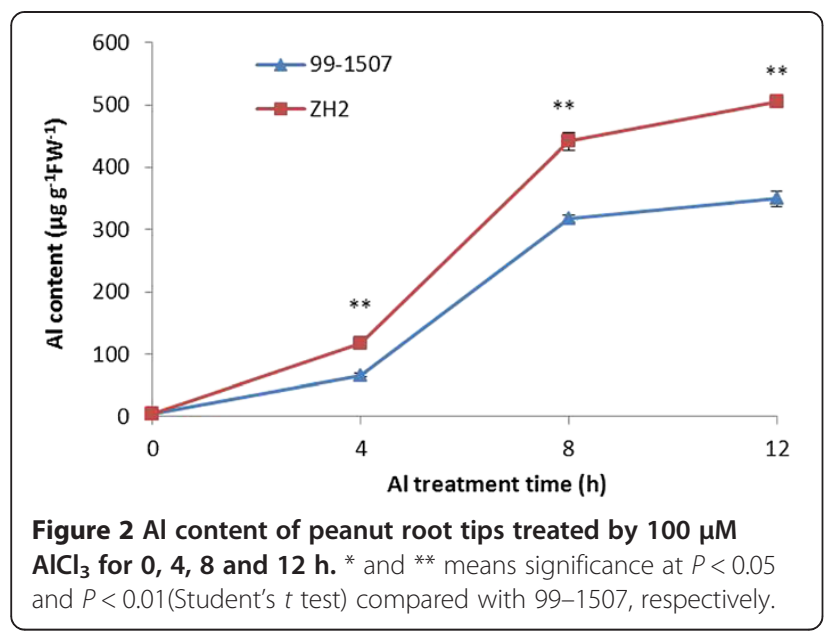

Morphological changes in nuclei and DNA fragment

Fluorescence microscopy clearly revealed DAPI-stained nucleus of peanut root tips under $100 \mu \mathrm{M} \mathrm{AlCl} 3$ stress for $0,4,8$ and $12 \mathrm{~h}$ (Figure 4 ). In the cortex of primary roots of control plants $(0 \mathrm{~h})$, nuclei were usually spherical and located in the middle of the cell. With the increase of $\mathrm{Al}$ treatment time, the arrays of cell were disorder, and the integrity of cell membrane was destroyed ( $8 \mathrm{~h}$ and $12 \mathrm{~h}$ ). Nuclei exposed to Al were flattened, lobed, invaginated or irregular in shape. The PCD ratios of root tip cells were significant difference between 99-1507 and ZH2. Treatment with $100 \mu \mathrm{M} \mathrm{AlCl}$

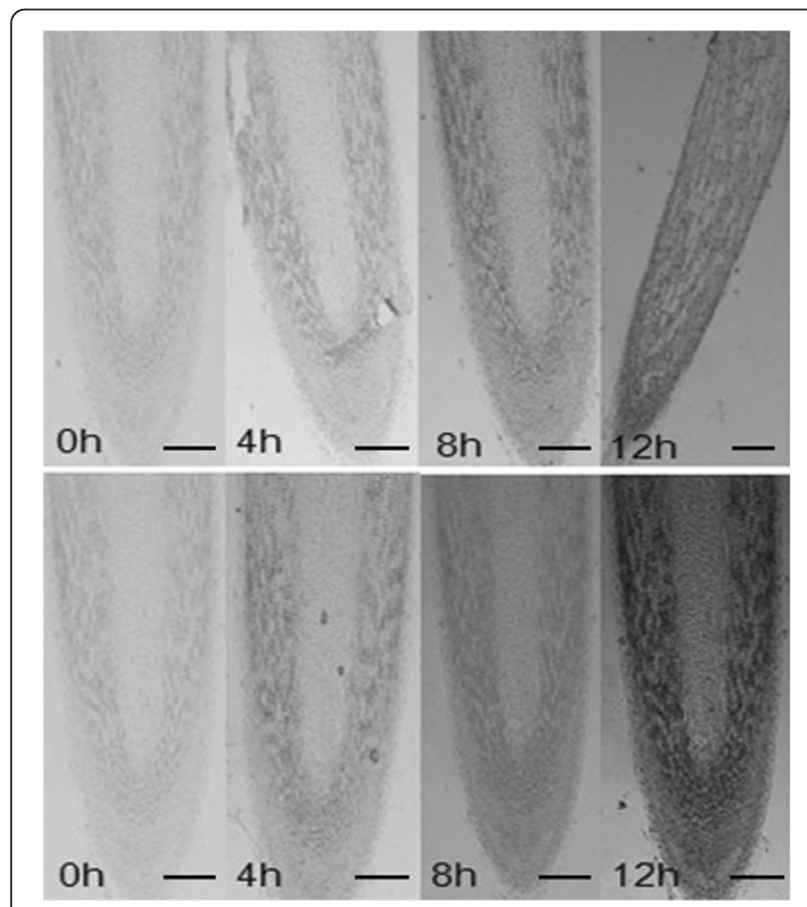

Figure 3 Hematoxylin-strained images of longitudinal sections of 99-1507 (up) and ZH2 (down) treated by Al for different hours (×50). Scale bar indicates $200 \mu \mathrm{m}$. induced PCD rapidly after $4 \mathrm{~h}$, while the PCD which was initiated by $\mathrm{Al}$ developed later in 99-1507 than in $\mathrm{ZH} 2$. The ratio of PCD increased significantly by Al treatment for $8 \mathrm{~h}$ and $12 \mathrm{~h}$, and it was significant between $\mathrm{ZH} 2$ and 99-1507 (Table 1).

DNA fragmentation was analyzed by electrophoresis on $2 \%$ agarose gel. There was no DNA ladder in 991507 and $\mathrm{ZH} 2$ under the control $\left(100 \mu \mathrm{M} \mathrm{AlCl} \mathrm{Al}_{3}\right.$ for $0 \mathrm{~h})$. DNA ladders were induced by $\mathrm{Al}$ treatment at $100 \mu \mathrm{M}$ for $4 \mathrm{~h}$ in $\mathrm{ZH} 2$ and 99-1507, and it was very weak in the 99-1507, but it was clear in ZH2. Small DNA ladder bands increased along with the increasing of Al treatment time, and it meaned that the degree of DNA damage increased (Figure 5). In the meanwhile, it showed that the DNA damage degree of $\mathrm{ZH} 2$ was more distinct than that of 99-1507.

\section{Hsr203j expression induced by $\mathrm{Al}$}

It has been reported that Hsr203 is a PCD-related gene in plants (Huang et al. 2004; Ma et al. 2010; Pontier et al. 2001; Pontier et al. 1994). To investigate the character of cell death events induced by $100 \mu \mathrm{M} \mathrm{AlCl}$, we analyzed the expression of $H s r 203 j$ in peanut root tip cells. There was not Hsr203j expression in root tip cells without $\mathrm{Al}$ treatment. Compared to the control, the expression of Hsr203j increased markedly after $100 \mu \mathrm{M}$ $\mathrm{AlCl}_{3}$ treatment, in particular at 8 and $12 \mathrm{~h}$ (Figure 6). The level of Hsr203j expression in $\mathrm{ZH} 2$ was higher than in $99-1507$ at the same treating time.

\section{Activation of caspase3-like protease}

To investigate whether caspase3-like protease was involved in in the process of Al stress-induced PCD, the activity of caspase3-like protease was analyzed. As shown in Figure 7, caspase3-like activity was in an absolutely low level without $\mathrm{Al}$ stress. $\mathrm{Al}$ treatment induced an increase in caspase3-like activity at 4, 8, and 12 h compared to the controls $(0 \mathrm{~h})$. What's more, caspase3-like protease activity values of $\mathrm{ZH} 2$ were always higher than those of 99-1507 at Al treatment in the period of 4-12 h.

\section{Release of Cyt c from mitochondria into cytosol}

During apoptosis in animal cells, the release of Cyt $c$ occurs before visible morphological changes. In order to determine whether peanut root tip cells underwent PCD during $\mathrm{Al}$ stress followed by the similar mitochondrial route as animal cell, we performed the immunoblotting detection of cytochrome $c$ in mitochondria and cytosol. Protein hybridization showed that Cyt $c$ band (about $14 \mathrm{kDa}$ ) was detected only in the mitochondria of control cells $(0 \mathrm{~h})$, but it could be detected in mitochondria and cytosol after Al stress, the bands became deep in cytosol and light in mitochondria along with the increase of $\mathrm{Al}$ treatment time both $99-1507$ and $\mathrm{ZH} 2$. In the 


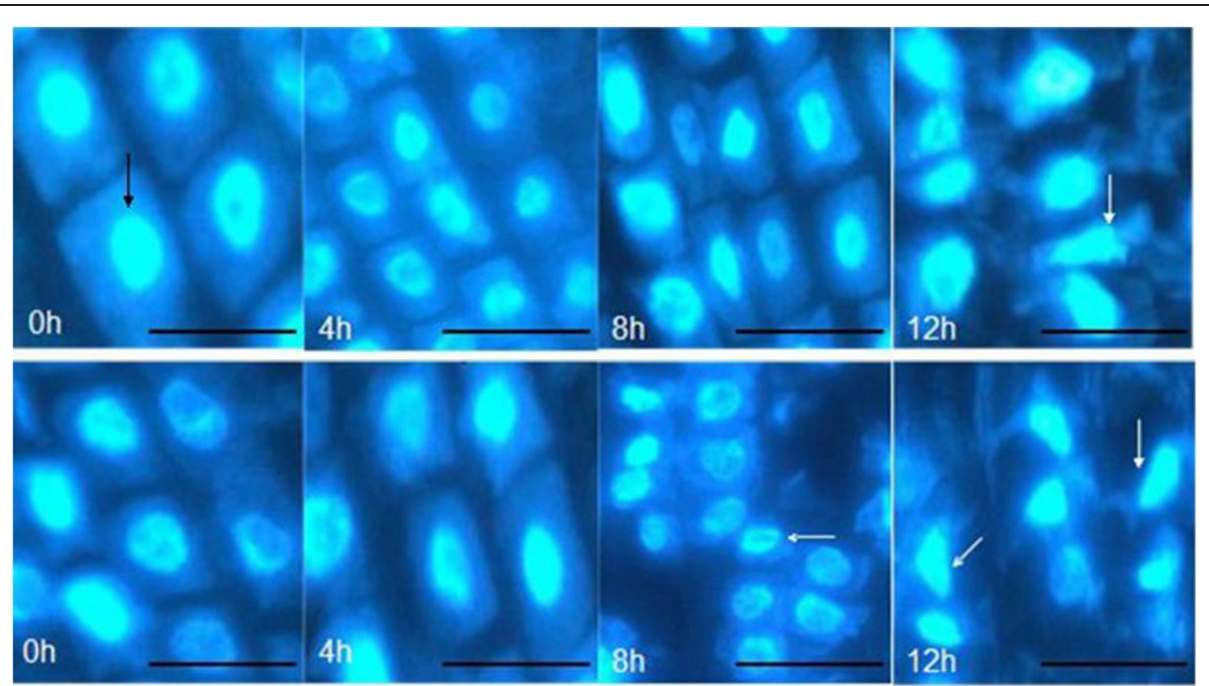

Figure 4 Morphology of DAPI-stained nuclei chromatin of root tip cells in 99-1507 (up) and ZH2 (down) after $100 \mu \mathrm{M} \mathrm{AICl}{ }_{3}$ treatment for different time. Scale bar indicates $25 \mu \mathrm{m}$. Black arrow indicates normal cell with spherical nuclei. White arrows mean apoptotic cell undergone cytoplasmic shrinking and fragmentation with condensed and distorted nuclei.

meanwhile, there was not band in mitochondria of $\mathrm{ZH} 2$ by $\mathrm{Al}$ treatment for $12 \mathrm{~h}$, but there was light band in mitochondria in 99-1507 (Figure 8). The results showed that Cyt $c$ released from mitochondria to cytosol after $\mathrm{Al}$ stress, and the speed of Cyt $c$ releasing was rapider in ZH2 than in 99-1507.

\section{Al caused MPTP opening and $\Delta \Psi_{m}$ collapse}

When cells underwent PCD, mitochondrial membrane permeability and mitochondrial permeability transition pore opening were enhanced. Compared to the controls $(0 \mathrm{~h})$, mitochondrial membrane permeability decreased significantly after $\mathrm{Al}$ stress for $4 \mathrm{~h}$, suggesting the opening of MPTP was increased by $\mathrm{Al}$ treatment. The mitochondrial membrane permeability was lower in ZH2 than in 99-1507 under $\mathrm{Al}$ stress for $4 \mathrm{~h}$. It revealed that $\mathrm{ZH} 2$ was more sensitive to $\mathrm{Al}$ stress than 99-1507. There was no significant difference in mitochondrial membrane permeability between $99-1507$ and ZH2 after $\mathrm{Al}$ treatment for 8 and $12 \mathrm{~h}$ (Figure 9).

Table 1 The PCD ratio of peanut root tip cells under $100 \mu \mathrm{M} \mathrm{AlCl}$

\begin{tabular}{ccc}
\hline Treatment time $(\mathbf{h})$ & $\mathbf{9 9 - 1 5 0 7}$ & $\mathbf{Z H 2}$ \\
\hline 0 & $0 \%$ & $0 \%$ \\
4 & $5 \pm 2.6 \% *$ & $9 \pm 1.2 \%$ \\
8 & $17 \pm 1.5 \% * *$ & $21 \pm 0.8 \%$ \\
12 & $23 \pm 1.8 \% * *$ & $30 \pm 1.4 \%$ \\
\hline
\end{tabular}

The cell PCD ratio was calculated as a percentage of apoptosis cells to total cells in one $400 \times$ microscopic field. More than 50 random fields were observed and calculated.

* and ${ }^{*}$ means significance at $P<0.05$ and $P<0.01$ (Student's $t$ test) compared with $\mathrm{ZH} 2$, respectively.
Rhodamine 123 (Rh-123) was used for monitoring the mitochondrial membrane potential shown by Emaus et al. (1986), Panda et al. (2008) and Zhan et al. (2009) in isolated mitochondria. Under $\mathrm{Al}$ treatment, the mitochondria showed a time-dependent decrease in inner membrane potential compared with the control (Figure 10). After treatment with $100 \mu \mathrm{M} \mathrm{AlCl}_{3}$ for $4 \mathrm{~h}$, the fluorescence intensity of Rh123 over all the protoplasts began to

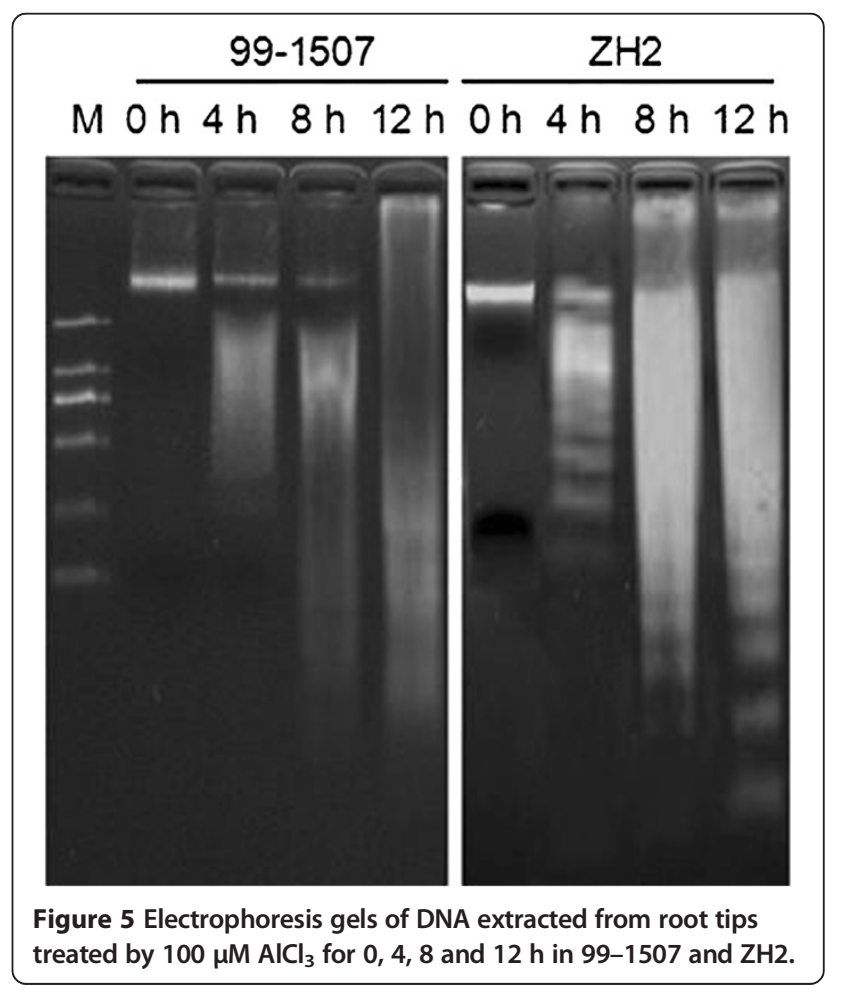




\section{$\frac{99-1507}{0 h \quad 4 h \quad 8 h \quad 12 h} \frac{\mathrm{ZH} 2}{0 h \quad 4 h \quad 8 h \quad 12 h}$

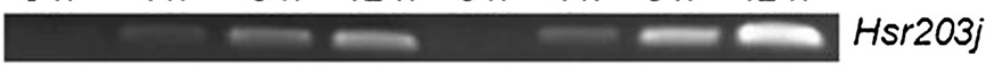

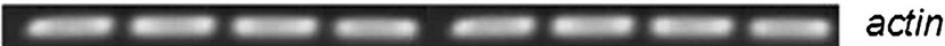

Figure 6 Expression of $H s r 203 J$ in root tip cells treated by $100 \mu \mathrm{M} \mathrm{AlCl}_{3}$ for $0,4,8$ and $12 \mathrm{~h}$ in $99-1507$ and ZH2. The expression level of actin was used as a positive internal control.

decrease. It decreased rapidly in ZH2 than in 99-1507 treated by $\mathrm{Al}$ for $4 \mathrm{~h}$, and a further decrease was observed at 8-12 h in the 99-1507.

\section{Al influenced ROS production in mitochondria}

Reactive oxygen belongs to the important markers of oxidative stress (Poborilova et al. 2013). Whether Al-treated cells were associated with the simultaneous production of hydrogen peroxide and superoxide anion radical in mitochondria was examined. Compared to the control, $\mathrm{Al}$ stress increased $\mathrm{O}_{2}{ }^{\cdot-}$ and $\mathrm{H}_{2} \mathrm{O}_{2}$ production in mitochondria from peanut root tips. The highest $\mathrm{O}_{2}{ }^{--}$and $\mathrm{H}_{2} \mathrm{O}_{2}$ levels in mitochondria was found after $\mathrm{Al}$ treatment for $4 \mathrm{~h}$ in 99-1507 and ZH2. The ROS production in the peanut roots which was isolated mitochondria under Al treatment increased in 0-4 $\mathrm{h}$ and decreased conspicuously in 8-12 h. ROS levels in Al-sensitive $\mathrm{ZH} 2$ were higher than in Al-tolerant 99-1507 under Al treatment (Figures 11 and 12). These results suggest that $\mathrm{Al}$ stress induced oxidative burst and oxidative stress in the mitochondria, and ROS participate in the $\mathrm{Al}$ toxicity and PCD induced by $\mathrm{Al}$.

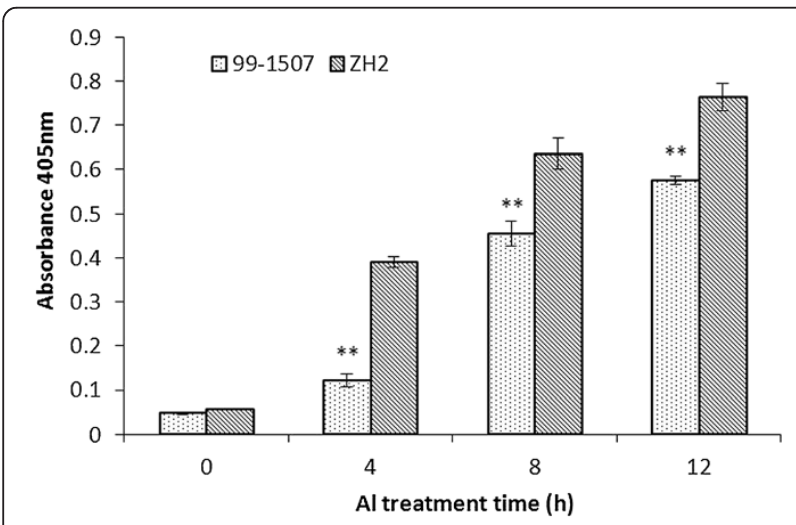

Figure 7 Activities of caspase3-like protease in root tip cells treated by $100 \mu \mathrm{M} \mathrm{AICl}$ for $0,4,8$ and $12 \mathrm{~h}$ in 99-1507 and ZH2. Caspase3-like protease activity was expressed as the absorbance in $405 \mathrm{~nm}$. Data represent the mean $( \pm \mathrm{SD})$ of three independent measurements. ${ }^{* *}$ means significance at $P<0.01$ (Student's $t$ test) in 99-1507 compared with ZH2.

\section{Discussion}

\section{Al induced rapidly PCD in root tips of peanut}

Much information has been gathered on the mechanisms of Al toxicity and tolerance (Panda and Matsumoto 2007). The initial and most dramatic symptom of Al toxicity is rapid inhibition of root elongation, and thus root relative elongation rate has served as a typical marker of levels of $\mathrm{Al}$ toxicity and tolerance in plants (Chandran et al. 2008; Pan et al. 2001; Reid et al. 1996). Our results showed that Al stress inhibited root elongation and increased $\mathrm{Al}$ content, but there was difference between two varieties, which explained the high tolerance of 99-1507 to Al stress compared to $\mathrm{ZH} 2$ (Figures 1, 2 and 3).

The cell death in plants can be classified as PCD or necrosis. PCD is induced by abiotic stresses which includes cold (Jeong et al. 2012), heat (Gupta et al. 2013; Mishkind et al. 2009), $\mathrm{Fe}^{2+}$ (Zhang et al. 2011), cadmium (Li et al. 2013), boron (Hamurcu et al. 2013; Siddiqui et al. 2013), salt (Lin et al. 2012; Poor et al. 2013; Wang et al. 2011), ROS (Liu et al. 2012), and hormones (Xing et al. 2013; Zhang and Xing 2008) in plants. Several studies found that some species of plant and suspension cultures undergo PCD after exposure to $\mathrm{Al}^{3+}$. Pan et al. (2001) reported that $0.1-50 \mathrm{mM} \mathrm{AlCl}_{3}$ induced a rapid decrease in root net growth rate, cell viability and distinct changes in cell morphology, and DNA integrity in barley. Similar results have been reported in suspension cells including tobacco (Panda et al. 2008) and tomato (Yakimova et al. 2007) and root tip cells of pea (Matsumoto and Motoda 2013), but the proofs were insufficient and there are not examples in oil crops. We certified first $\mathrm{Al}$ induced $\mathrm{PCD}$ in two peanut cultivars: ZH2 (Al-sensitive) and 99-1507 (Al-tolerant) by DNA ladder, TUNEL detection and electron microscopy, and found that the concentration of Al-induced PCD was lower in ZH2 than in 99-1507 (Zhan et al. 2013). The time of $\mathrm{Al}$ inducing $\mathrm{PCD}$ in peanut was 4 days (Zhan et al. 2013), it is too long to research the regulation mechanism of $\mathrm{Al}$ induced PCD. In this study, DNA fragment were observed in root tip cells treated with $100 \mu \mathrm{M} \mathrm{AlCl} \mathrm{Al}_{3}$ for $4 \mathrm{~h}$ (Figure 5). Condensation and degradation of nuclear chromatin were also observed after DAPI staining (Figure 4). These results were in 


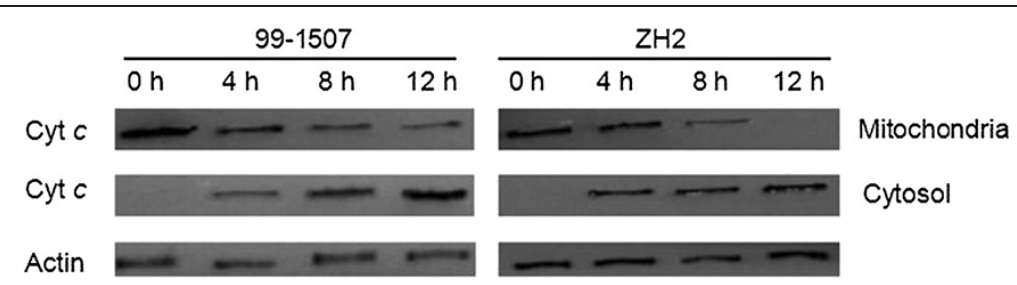

Figure 8 Protein hybridization analysis of Cyt $c$ in mitochondria and cytosol of peanut root tip cells treated by $100 \mu \mathrm{M} \mathrm{AICl}{ }_{3}$ for $0,4,8$ and12 $\mathbf{h}$. Equal loading was verified by anti-actin immunoblotting.

agreement with the data of $\mathrm{Fu}$ et al. (2003), indicating that these hallmarks were typical not only of the animal but also of plant cell death processes during $\mathrm{Al}$-induced PCD (He et al. 2012). Hsr203j has been shown to be a molecular marker of the hypersensitive response (HR) (Pontier et al. 2001). The increase of Hsr203j expression was taken as a hallmark of Cd induced PCD (Ma et al. 2010). Our results showed that Hsr203j expression was a sensitive hallmark for $\mathrm{Al}$-induced PCD in peanut. There was not the expression of $H s r 203 j$ in root tip cells without $\mathrm{Al}$ treatment, but $100 \mu \mathrm{M} \mathrm{AlCl}$ induced markedly the expression of $\mathrm{Hsr} 203 \mathrm{j}$ especial in 8 and $12 \mathrm{~h}$ (Figure 6).

Taken together, these results indicate that Al triggers rapidly $\mathrm{PCD}$ in peanut. It certifies further that there is a negative relationship between $\mathrm{Al}$-induced PCD and Al-resistance in peanut (Zhan et al. 2013). To inhibit Al-induced PCD is one of protective mechanism to $\mathrm{Al}$ stress in plant.

\section{PCD induced rapidly by $\mathrm{Al}$ in peanut was mitochondria dependent}

Although recent evidence has shown that $\mathrm{Al}$ toxicity induced cell death in plants, animals and yeasts (Fu et al. 2003; Li et al. 2011; Toninello et al. 2000), the molecular mechanisms of Al-triggering evolutionarily-conserved PCD pathways have remained elusive.

Caspases are responsible for initiating, executing and signal transduction of animal PCD. Caspase-dependent as well as caspase-independent apoptosis has been described in animal cells, and the presence of caspase3like activities is one of the peculiar biochemical features of PCD (Matsumura et al. 2000). Animals have caspase genes; plants do not have orthologous sequences in their genomes. The existence of caspase-like proteases has been demonstrated experimentally in plants by the applications of artificial synthesized substrates and inhibitors of caspase (Li and Xing 2011; Poor et al. 2013; Wang et al. 2010). Our results showed that aspase3-like protease activity was lower without $\mathrm{Al}$ stress; it increased markedly with $\mathrm{Al}$ treatment at $100 \mu \mathrm{M}$ Al. The caspase3-like protease activity of ZH2 was higher than that of 99-1507 at different $\mathrm{Al}$ treatment time (Figure 7). Not only the results suggest there is caspase3-like protease in peanut root tips, but it play role in Al-induced PCD. Caspaselike proteases can be divided into three classes: metacaspases, vacuolar processing enzymes (VPEs), and saspases (Zhan et al. 2012). Some studies showed that saspases were involved in the proteolytic degradation of ribulose-1,5-bisphosphate carboxylase/oxygenase (Rubisco)

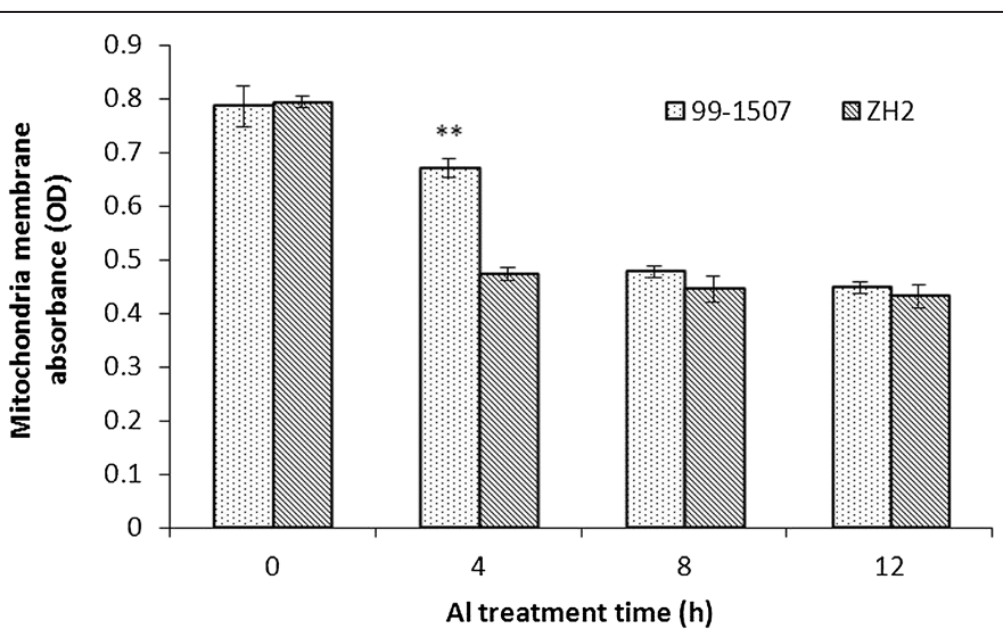

Figure 9 Effects of $100 \mu \mathrm{M} \mathrm{AlCl}_{3}$ for $0,4,8$ and $12 \mathrm{~h}$ on membrane permeability of mitochondria in peanut root tip cells. ${ }^{* *}$ means significance at $P<0.01$ (Student's $t$ test) compared with $\mathrm{ZH} 2$. 


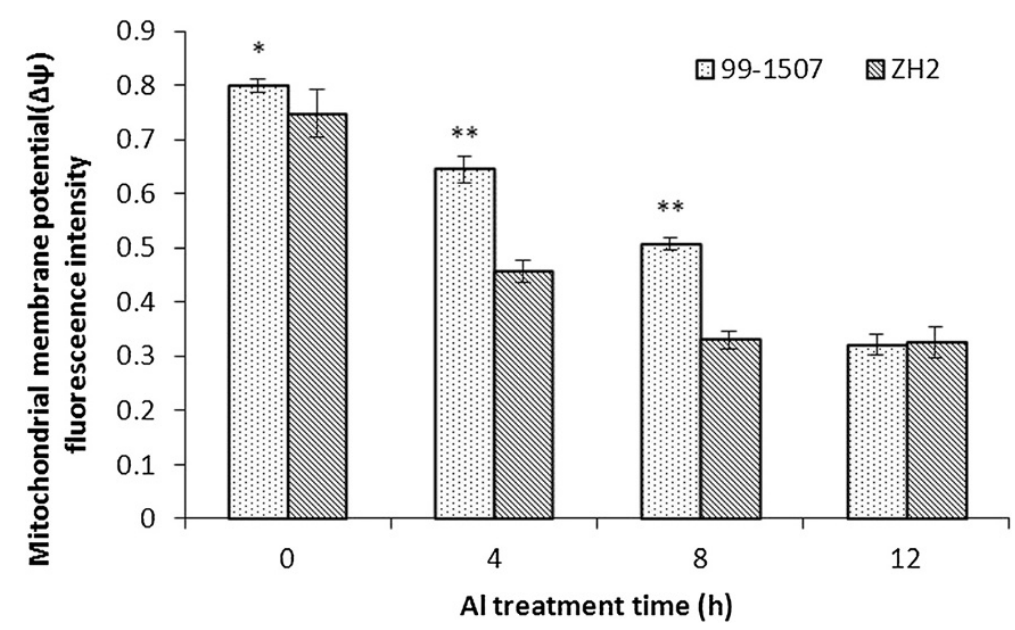

Figure 10 Effects of $100 \mu \mathrm{M} \mathrm{AICl}_{3}$ for $0,4,8$ and $12 \mathrm{~h}$ on $\Delta \Psi_{\mathrm{m}}$ in peanut root tip cells. ${ }^{*}$ and ${ }^{* *}$ means significance at $P<0.05$ and $P<0.01$ (Student's t test) compared with $\mathrm{ZH} 2$, respectively.

in biotic and abiotic PCD, whereas phytaspase overproducing and silenced transgenics provide evidence that phytaspase regulates PCD during both abiotic (oxidative and osmotic stresses) and biotic (virus infection) insults (Vartapetian et al. 2011). To certify the types and the roles of caspase-like protease induced by $\mathrm{Al}$ in peanut root tips are next important research field.

Mitochondria play a key role in cellular metabolism and the regulation of PCD. Cyt $c$ release has been certified in plant cells under-going opening of MPTP and subsequent PCD under the influence of biotic and abiotic stress conditions (Panda et al. 2008; Tiwari et al. 2002). Our results showed that $\mathrm{Al}$ increased mitochondrial membrane permeability and MPTP opening (Figure 9), decreased inner membrane potential of mitochondria (Figure 10), and released Cyt $c$ from mitochondria to cytosol (Figure 8). Cyt $c$ released rapidly after $\mathrm{Al}$ stress, which was earlier than DNA laddering and caspase3-like protease activation. It suggests that there are close relationship among mitochondrial membrane permeability, MPTP opening, inner membrane potential, Cyt $c$ release, caspase3-like protease activation, and $\mathrm{PCD}$ production. These changes maybe occur in sequence. Mitochondria swelling enhance mitochondrial membrane permeability, result in the loss of inner membrane potential, enlarge mitochondrial permeability transition pore, and release Cyt $c$. In animals, apoptotic signals cause the loss of $\Delta \Psi_{\mathrm{m}}$ through signal transduction pathways, thereby release apoptosis-inducing factors such as Cyt $c$, consequently activate caspases, and lead cell death (Fu et al. 2003; Kim et al. 2006; Kroemer et al. 2007).

A large difference between 99-1507 and ZH2 was observed in the values of MPTP, $\Delta \Psi_{\mathrm{m}}$ and Cyt $c$ release after $\mathrm{Al}$ treatment. The absorbance value was higher in

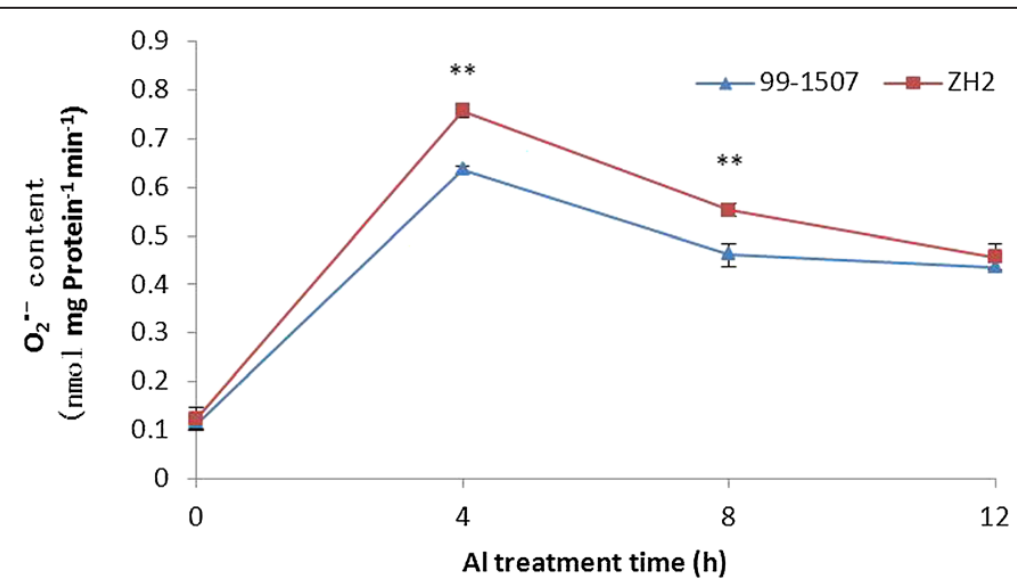

Figure 11 Superoxide anion radical production of mitochondria in peanut root tip cells. ${ }^{* *}$ means significance at $P<0.01$ (Student's $t$ test) compared with 99-1507. 


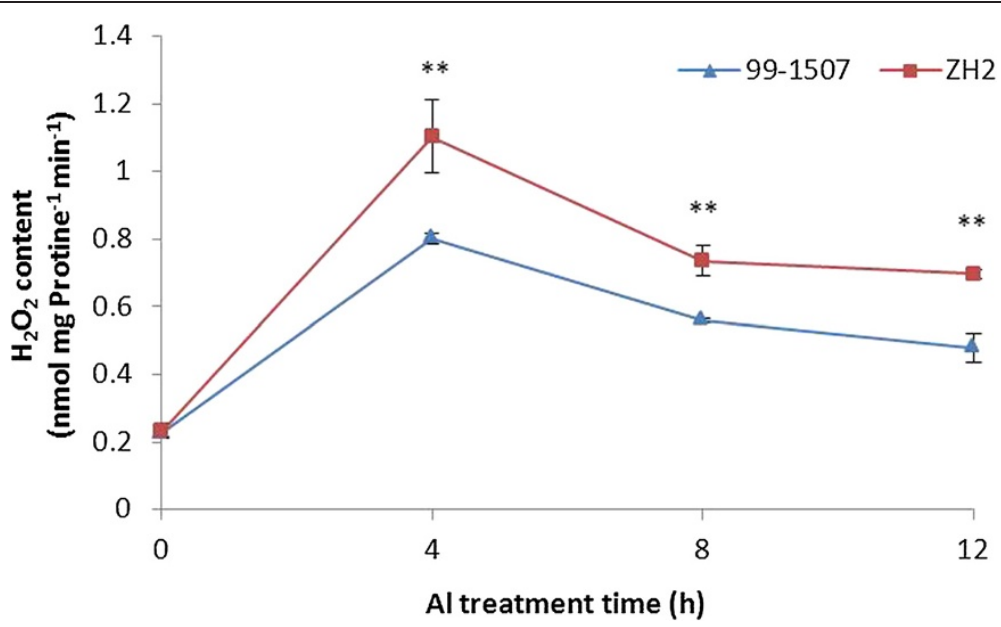

Figure 12 Hydrogen peroxide production of mitochondria in peanut root tip cells. ${ }^{* *}$ means significance at $P<0.01$ (Student's $t$ test) compared with 99-1507.

99-1507 than in $\mathrm{ZH} 2$ treated by $\mathrm{Al}$ for $4 \mathrm{~h}$; however, there were no significant difference between the control $(0 \mathrm{~h})$ and $\mathrm{Al}$ treatments for 8 and $12 \mathrm{~h}$. The values of $\Delta \Psi_{\mathrm{m}}$ decreased with the increment of Al treatment time, and it was the lowest level at $8 \mathrm{~h}$ in Al-sensitive $\mathrm{ZH} 2$ and at $12 \mathrm{~h}$ in Al-tolerant 99-1507. It could be suggested that the stress time threshold of Al-induced PCD in Al-tolerant peanut cultivar is longer than that in $\mathrm{Al}$ sensitive cultivar. That is to say, there is a negative relationship between $\mathrm{PCD}$ and $\mathrm{Al}$ resistance in peanut on $\mathrm{Al}$ treatment time as well as on $\mathrm{Al}$ treatment concentration.

It is well known that ROS act as important signal molecules in triggering PCD (Liu and Lin 2013; Maksymiec 2007; Matsumoto and Motoda 2013; Xing et al. 2013). Mitochondria have received considerable attention in the investigation of ROS-dependent PCD (Panda et al. 2008). Many reports have shown that Al stress can induce ROS production, which is an important component of the plant's reaction to toxic levels of $\mathrm{Al}$ ( $\mathrm{Li}$ and Xing 2011; Matsumoto and Motoda 2013; Pan et al. 2001; Pan et al. 2002; Panda et al. 2008; Xu et al. 2011). Thus, it is very likely that $\mathrm{Al}$ stress indirectly initiates plant PCD through inducing ROS generation. Current evidences suggested that low dose of ROS can induce antioxidant enzymes and alleviate Al-induced oxidative stress (Xu et al. 2011), however, when the concentration of ROS reaches a certain threshold, a signal transduction pathway which results in PCD is activated, high doses of ROS result in necrosis (Solomon et al. 1999). In our experiments, a rapid burst of ROS formation occurred in Al-treated protoplasts for $4 \mathrm{~h}$, and the ROS generated from mitochondria were demonstrated to be involved in the oxidative burst induced by $\mathrm{Al}$ (Figures 11 and 12). One hundred $\mu \mathrm{M} \mathrm{AlCl}$, obviously, is an appropriate concentration to activate ROS burst leading PCD in peanut. The ROS burst provoked by $\mathrm{Al}$ were higher in Al-sensitive cultivar $\mathrm{ZH} 2$ than in Al-tolerant cultivar 99-1507. It indicated that ROS acted as signal molecules in Al-induced protoplast PCD, and the burst of ROS was an early event in this process.

In consideration of all these data, $\mathrm{Al}$ induced rapidly PCD in root tips of peanut, ROS of mitochondria involved in this PCD process. The PCD was mitochondria dependence, and it can be explained by the model of acceleration of senescence under $\mathrm{Al}$ treatments (Zhan et al. 2013). Besides, caspase3-like protease locates between Cyt $c$ and PCD. The difference between Altolerant and Al-sensitive genotype is that it is easier and faster to induce $\mathrm{ROS}$ burst by $\mathrm{Al}$ in $\mathrm{Al}$-sensitive genotype than in Al-tolerant genotype.

\section{Conclusions}

$\mathrm{Al}$ induced rapidly $\mathrm{PCD}$ in peanut root tip cells, which was earlier and faster in $\mathrm{Al}$-sensitive peanut cultivar than in Al-tolerant cultivar. There is a negative relationship between PCD and $\mathrm{Al}$ resistance. Al-induced PCD was mitochondria-dependence in peanut, and ROS was involved in this process. The mechanism can be explained by the model of acceleration of senescence under Al stress.

\section{Abbreviations}

Al: Aluminum; Cytc. Cytochrome C; DAPI: 4', 6-diamidino-2-phenylindol dihydrochloride; EDTA: Ethylene diaminetetraacetic acid; EGTA: Ethylene glycol bis (2-aminoethyl) tetraacetic acid; HEPES: 4-(2-Hydroxyethy)-1-piperazineethanesulfonic acid; LM: Light microscopy; MPTP: Mitochondrial permeability transition pores; PBS: Phosphate buffer saline; PCD: Programmed cell death; PCR: Polymerase chain reaction; ROS: Reactive oxygen species; Tris: Tris (hydroxymethyl) aminomethane; $\Delta \Psi_{m}$ : Mitochondria membrane potential.

\section{Competing interests}

The authors declare that they have no competing interests. 


\section{Authors' contributions}

LFH and AQW conceptualized the project, designed the experimental procedures, analyzed the data and revised the manuscript. WJH conducted the measure of Al content; root elongation; cell death; gene expression and detection of ROS, analyzed the data and wrote the manuscript. TLO and HYH performed the experiments regarding to the mitochondria. JZ; SQW and CZL cultured the plant. All authors read and approved the final manuscript.

\section{Acknowledgments}

This work was supported by National Natural Science Foundation of China (No. 31260296, 31301249, and 30960181).

\section{Received: 13 February 2014 Accepted: 23 August 2014}

Published: 3 September 2014

\section{References}

Achary VMM, Panda BB (2010) Aluminium-induced DNA damage and adaptive response to genotoxic stress in plant cells are mediated through reactive oxygen intermediates. Mutagenesis 25:201-209

Barry S, Adam F (1984) Measurement of aluminium in dialysis is fluid and water by a spectrophotometric procedure. Analyst 109:369-372

Bradford MM (1976) A rapid and sensitive method for the quantitation of microgram quantities of protein utilizing the principle of protein-dye binding. Anal Biochem 72:248-254

Braidot E, Petrussa E, Macri F, Vianello A (1998) Plant mitochondrial electrical potential monitored by fluorescence quenching of rhodamine 123. Biol Plant 41:193-201

Chandran D, Sharopova N, Ivashuta S, Gantt JS, VandenBosch KA, Samac DA (2008) Transcriptome profiling identified novel genes associated with aluminum toxicity, resistance and tolerance in Medicago truncatula. Planta 228:151-166

Emaus RK, Grunwald R, Lemasters JJ (1986) Rhodamine 123 as a probe of transmembrane potential in isolated rat-liver mitochondria: spectral and metabolic properties. Biochim Biophys Acta 850:436-448

Foyer $\mathrm{CH}$, Noctor $\mathrm{G}$ (2000) Oxygen processing in photosynthesis: regulation and signalling. New Phytol 146:359-388

Fu HJ, Hu QS, Lin ZN, Ren TL, Song H, Cai CK, Dong SZ (2003) Aluminuminduced apoptosis in cultured cortical neurons and its effect on SAPK/JNK signal transduction pathway. Brain Res 980:11-23

Gladish DK, Xu JP, Niki T (2006) Apoptosis-like programmed cell death occurs in procambium and ground meristem of pea (Pisum sativum) root tips exposed to sudden flooding. Ann Bot 97:895-902

Gupta NK, Agarwal S, Agarwal VP, Nathawat NS, Gupta S, Singh G (2013) Effect of short-term heat stress on growth, physiology and antioxidative defence system in wheat seedlings. Acta Physiol Plant 35:1837-1842

Hamurcu M, Sekmen AH, Turkan I, Gezgin S, Demiral T, Bell RW (2013) Induced anti-oxidant activity in soybean alleviates oxidative stress under moderate boron toxicity. Plant Growth Regul 70:217-226

He B, Liang J (1996) Highly sensitive spectrophotometric determination aluminium in plant and soil water with chromazurol $\mathrm{S}$, cetyltrimethylammonium bromide and alcohol. J Guangxi Agricultural University 15(2):151-155

He Q, You R (2004) Steedman's Wax sectioning for observation of the microtubule cytoskeleton in plant cells. Chinese Bulletin of Botany 21:547-555

He H, Zhan J, He L, Gu M (2012) Nitric oxide signaling in aluminum stress in plants. Protoplasma 249:483-492

Huang HE, Ger MJ, Yip MK, Chen CY, Pandey AK, Feng TY (2004) A hypersensitive response was induced by virulent bacteria in transgenic tobacco plants overexpressing a plant ferredoxin-like protein (PFLP). Physiol Mol Plant Pathol 64:103-110

Jeong YJ, Choy YH, Joo HJ, Hwang JH, Byun YJ, Ha-Lee YM, Lee JS, Jang YS, Lee DH (2012) Identification and analysis of cold stress-inducible genes in Korean rapeseed varieties. J Plant Biol 55:498-512

Kim R, Emi M, Tanabe K (2006) Role of mitochondria as the gardens of cell death. Cancer Chemother Pharmacol 57:545-553

Kroemer G, Galluzzi L, Brenner C (2007) Mitochondrial membrane permeabilization in cell death. Physiol Rev 87:99-163

Li Z, Xing D (2011) Mechanistic study of mitochondria-dependent programmed cell death induced by aluminium phytotoxicity using fluorescence techniques. J Exp Bot 62:331-343
Li X, Qian J, Wang C, Zheng K, Ye L, Fu Y, Han N, Bian H, Pan J, Wang J, Zhu M (2011) Regulating cytoplasmic calcium homeostasis can reduce aluminum toxicity in yeast. PLoS One 6(6):e21148

Li FT, Qi JM, Zhang GY, Lin LH, Fang PP, Tao AF, Xu JT (2013) Effect of cadmium stress on the growth, antioxidative enzymes and lipid peroxidation in two kenaf (Hibiscus cannabinus L.) Plant Seedlings. J Integr Agric 12:610-620

Lin Y, Liu Z, Shi Q, Wang X, Wei M, Yang F (2012) Exogenous nitric oxide (NO) increased antioxidant capacity of cucumber hypocotyl and radicle under salt stress. Sci Hortic 142:118-127

Liu N, Lin ZF (2013) Reactive oxygen species and alternative respiration in the developing flowers of Two subtropical woody plants. J Plant Growth Regul 32:83-91

Liu SG, Zhu DZ, Chen GH, Gao XQ, Zhang XS (2012) Disrupted actin dynamics trigger an increment in the reactive oxygen species levels in the Arabidopsis root under salt stress. Plant Cell Rep 31:1219-1226

Ma W, Xu W, Xu H, Chen Y, He Z, Ma M (2010) Nitric oxide modulates cadmium influx during cadmium-induced programmed cell death in tobacco BY-2 cells. Planta 232:325-335

Maksymiec W (2007) Signaling responses in plants to heavy metal stress. Acta Physiol Plant 29:177-187

Matsumoto H, Motoda H (2013) Oxidative stress is associated with aluminum toxicity recovery in apex of pea root. Plant Soil 363:399-410

Matsumura H, Shimizu Y, Ohsawa Y, Kawahara A, Uchiyama Y, Nagata S (2000) Necrotic death pathway in Fas receptor signaling. J Cell Biol 151:1247-1255

Mishkind M, Vermeer JEM, Darwish E, Munnik T (2009) Heat stress activates phospholipase D and triggers PIP2 accumulation at the plasma membrane and nucleus. Plant J 60:10-21

Mittler R, Vanderauwera S, Gollery M, Van Breusegem F (2004) Reactive oxygen gene network of plants. Trends Plant Sci 9:490-498

Pan JW, Zhu MY, Chen H (2001) Aluminum-induced cell death in root-tip cells of barley. Environ Exp Bot 46:71-79

Pan JW, Zhu MY, Chen H, Han N (2002) Inhibition of cell growth caused by aluminum toxicity results from aluminum-induced cell death in barley suspension cells. J Plant Nutr 25:1063-1073

Panda SK, Matsumoto H (2007) Molecular physiology of aluminum toxicity and tolerance in plants. Bot Rev 73:326-347

Panda SK, Yamamoto Y, Kondo H, Matsumoto H (2008) Mitochondrial alterations related to programmed cell death in tobacco cells under aluminium stress. C R Biol 331:597-610

Poborilova Z, Opatrilova R, Babula P (2013) Toxicity of aluminium oxide nanoparticles demonstrated using a BY-2 plant cell suspension culture model. Environ Exp Bot 91:1-11

Pontier D, Godiard L, Marco Y, Roby D (1994) hsr203J, a tobacco gene whose activation is rapid, highly localized and specific for incompatible plant/ pathogen interactions. Plant J 5:507-521

Pontier D, Balague C, Bezombes-Marion I, Tronchet M, Deslandes L, Roby D (2001) Identification of a novel pathogen-responsive element in the promoter of the tobacco gene HSR203J, a molecular marker of the hypersensitive response. Plant J 26:495-507

Poor P, Kovacs J, Szopko D, Tari I (2013) Ethylene signaling in salt stress- and salicylic acid-induced programmed cell death in tomato suspension cells. Protoplasma 250:273-284

Purvis AC (1997) Role of the alternative oxidase in limiting superoxide production by plant mitochondria. Physiol Plant 100:165-170

Qiao JJ, Yuan YJ, Zhao H, Wu JC (2003) Differences in protein patterns in suspension cultures of Taxus cuspidata induced by cerium. Biol Plant 46:611-615

Reid RJ, Rengel Z, Smith FA (1996) Membrane fluxes and comparative toxicities of aluminium, scandium and gallium. J Exp Bot 47:1881-1888

Siddiqui MH, Al-Whaibi MH, Sakran AM, Ali HM, Basalah MO, Faisal M, Alatar A, Al-Amri AA (2013) Calcium-induced amelioration of boron toxicity in radish. J Plant Growth Regul 32:61-71

Solomon M, Belenghi B, Delledonne M, Menachem E, Levine A (1999) The involvement of cysteine proteases and protease inhibitor genes in the regulation of programmed cell death in plants. Plant Cell 11:431-443

Tiwari BS, Belenghi B, Levine A (2002) Oxidative stress increased respiration and generation of reactive oxygen species, resulting in ATP depletion, opening of mitochondrial permeability transition, and programmed cell death. Plant Physiol 128:1271-1281

Toninello A, Clari G, Mancon M, Tognon G, Zatta P (2000) Aluminum as an inducer of the mitochondrial permeability transition. J Biol Inorg Chem 5:612-623 
Vartapetian AB, Tuzhikov Al, Chichkova NV, Taliansky M, Wolpert TJ (2011) A plant alternative to animal caspases: subtilisin-like proteases. Cell Death Differ 18:1289-1297

Wang W, Pan J, Zheng K, Chen H, Shao H, Guo Y, Bian H, Han N, Wang J, Zhu M (2009) Ced-9 inhibits Al-induced programmed cell death and promotes A tolerance in tobacco. Biochem Biophys Res Commun 383:141-145

Wang J, Li X, Liu Y, Zhao X (2010) Salt stress induces programmed cell death in Thellungiella halophila suspension-cultured cells. J Plant Physio 167:1145-1151

Wang J, Li X, Liu Y, Zhao X, Chen C, Tian F (2011) MEK/ERK inhibitor U0126 enhanced salt stress-induced programmed cell death in Thellungiella halophila suspension-cultured cells. Plant Growth Regul 63:207-216

Wang GP, Zhang ZH, Kong DJ, Liu QX, Zhao GL (2012) Programmed cell death is responsible for replaceable bud senescence in chestnut (Castanea mollissima BL.). Plant Cell Rep 31:1603-1610

Wei MY, Chao YY, Kao CH (2013) NaCl-induced heme oxygenase in roots of rice seedlings is mediated through hydrogen peroxide. Plant Growth Regul 69:209-214

Xing F, Li Z, Sun A, Xing D (2013) Reactive oxygen species promote chloroplast dysfunction and salicylic acid accumulation in fumonisin B1-induced cell death. FEBS Lett 587:2164-2172

Xu FJ, Jin CW, Liu WJ, Zhang YS, Lin XY (2011) Pretreatment with $\mathrm{H}_{2} \mathrm{O}_{2}$ alleviates aluminum-induced oxidative stress in wheat seedlings. J Integr Plant Biol 53:44-53

Yakimova ET, Kapchina-Toteva VM, Woltering EJ (2007) Signal transduction events in aluminum-induced cell death in tomato suspension cells. J Plant Physiol 164:702-708

Yamamoto Y, Kobayashi Y, Devi SR, Rikiishi S, Matsumoto H (2002) Aluminum toxicity is associated with mitochondrial dysfunction and the production of reactive oxygen species in plant cells. Plant Physiol 128:63-72

Zhan J, Kou RJ, He LF (2008) Effects of aluminum on morphological structure of peanut root tips. Chinese J Oil Crop Sci 30:79-83

Zhan J, Kou RJ, Li CZ, He HY, He LF (2009) Effects of aluminum on physiological characteristics of mitochondrial membrane in peanut root tips. Acta Agron Sin 35:1059-1067

Zhan J, Wang T, He H, Li C, He L (2011) Effects of SNP on AhSAG and AhBl-1 genes expression and amelioration of aluminum stress to peanut (Arachis hypoganea L.). Acta Agron Sin 37:459-468

Zhan J, He HY, Li W, He LF (2012) Progress in caspase-like proteases and their regulatory roles in programmed cell death in plants. Plant Physiology $\mathrm{J}$ 48:435-441

Zhan J, He HY, Wang TJ, Wang AQ, Li CZ, He LF (2013) Aluminum-induced programmed cell death promoted by AhSAG, a senescence-associated gene in Arachis hypoganea L. Plant Sci 210:108-117

Zhang L, Xing D (2008) Methyl jasmonate induces production of reactive oxygen species and alterations in mitochondrial dynamics that precede photosynthetic dysfunction and subsequent cell death. Plant Cell Physiol 49:1092-1111

Zhang Y, Zheng GH, Liu P, Song JM, Xu GD, Cai MZ (2011) Morphological and physiological responses of root tip cells to $\mathrm{Fe}^{2+}$ toxicity in rice. Acta Physiol Plant 33:683-689

Zheng K, Pan JW, Ye L, Fu Y, Peng HZ, Wan BY, Gu Q, Bian HW, Han N, Wang JH, Kang B, Pan JH, Shao HH, Wang WZ, Zhu MY (2007) Programmed cell death-involved aluminum toxicity in yeast alleviated by antiapoptotic members with decreased calcium signals. Plant Physiol 143:38-49

\section{doi:10.1186/s40529-014-0067-}

Cite this article as: Huang et al:: Aluminum induces rapidly

mitochondria-dependent programmed cell death in Al-sensitive peanut root tips. Botanical Studies 2014 55:67. 